\title{
Soaking and Drying Effect on the Functional Properties of Ogi Produce from Some Selected Maize Varieties
}

\author{
Bolaji O.T. , Oyewo A.O, Adepoju P.A \\ Department of Food Technology Ikorodu Lagos Lagos State Polytechnic \\ *Corresponding author: olusholat@yahoo.com
}

Received August 15, 2014; Revised October 20, 2014; Accepted October 28, 2014

\begin{abstract}
This study evaluated the effect of soaking period (12, 24 and 36 hours) and drying temperature (40,50 and $60^{\circ} \mathrm{C}$ ) on the functional properties of Ogi powder produced from four different maize varieties; A5W, A4Y, D1Y and S7Y. The moisture content and drying rate decreased significantly $(p<0.05)$ with increase in time and drying temperature. There were no significant difference $(\mathrm{p}>0.05)$ in Bulk Density, Sedimentation and Swelling Power. The result revealed that sedimentation volumes were not influenced by processing methods while starch damage of the Ogi powders varies from 92.03 to $95.02 \%$. This increased with increase in drying temperature. Ogi powders had least gelation of $8 \%$ for all the maize varieties. There were significant differences $(p<0.05)$ in Viscosity, Solubility, Water Absorption Capacities (WAC) and Oil Absorption Capacities (OAC). Ogi powder produced from A4Y variety and soaked for 12 hours exhibited higher WAC values at $50^{\circ} \mathrm{C}$. This variety also displayed higher values of water absorption capacity at all temperatures. Solubility, viscosity and swelling power increased with increase in temperature. The viscosity of the Ogi powders pastes ranged from 1200-1794 cps, and 804- 1540 at 80 and $30^{\circ} \mathrm{C}$, respectively. Ogi powders produced from D1Y and S7Y exhibited higher degree of retrogradation. Differences observed in the functional properties among varieties highlight the possible application of end-product suitability in Ogi powder processing.
\end{abstract}

Keywords: Ogi, Maize, soaking, drying, viscosities, functional properties

Cite This Article: Bolaji O.T., Oyewo A.O, and Adepoju P.A, "Soaking and Drying Effect on the Functional Properties of Ogi Produce from Some Selected Maize Varieties." American Journal of Food Science and Technology, vol. 2, no. 5 (2014): 150-157. doi: 10.12691/ajfst-2-5-3.

\section{Introduction}

Ogi is a common weaning food or adult gruel produced from cereals like Sorghum, Maize and Millet). Ogi is a popular breakfast cereal and infant weaning food in Nigeria (Banigo and Muller, 1972; Odunfa, 1985; Okoruwa, 1997). The wet Ogi can be boiled at 8-10\% total solids into a porridge or pap which serves as weaning food for infants, breakfast for children and convenient meal (Onyekwere et al., 1989). It is also known as 'Eko', 'Agidi', 'Akamu', and 'Koko' in Nigeria. The traditional production process involves soaking of maize grains in cold water for 1-3 days after which the water is decanted (Akinrele, 1970; Odunfa and Adeyele, 1985; Ohenhen and Ikenebomeh, 2007). The soaked grains are wet milled and sieved using muslin cloth and the filtrate is fermented for 2-3 days to yield wet Ogi, which is a sour, starchy sediment (Akinrele, 1970; Odunfa and Adeyele, 1985; Ohenhen and Ikenebomeh, 2007). The physical and biochemical qualities of Ogi were reported to be influenced by the type of cereal grain, fermentation or souring periods and the milling method (Banigo and Muller, 1972; Akingbala, 1981; Osungbaro, 1990). Aderiye and Laleye (2003) reported that Ogi is a very important food to the rural communities in Southern
Nigeria. According to these researchers, Garri and Ogi were the most frequently consumed fermented foods in that area. Also, Ajayi (2004) showed that cereal grain processing industries, using maize as their raw material to produce Ogi, constituted about $11.19 \%$ of the total food processing industries in rural Oyo State, Nigeria (Ajayi, 2004).

Many researchers have reported factors affecting the textural quality of Ogi porridge. These include the type of cereal grains, variety, milling technique; particle sizes; steeping and fermentation periods (Amoa and Muller, 1976; Klaus and Hinz, 1976; Adeyemi, 1983; Adeyemi and Beckley, 1986; Osungbaro, 1990a; Osungbaro 1990b). Ogi had been successfully prepared using dry milled sorghum and maize flours (Umoh and Fields, 1981; Adeyemi, 1983; Osungbaro, 1990a). The dry milling was considered more convenient than wet milling process, since the flour could be dispensed and packaged to consumers for subsequent steeping and fermentation. Drying Ogi will aid ease of fortification and shelf life (Edema et al., 2005; Fasasi et al., 2007; Otunola et al., 2006; Aminigo and Akingbala, 2004).

It is with the understanding of the importance of drying reported for Ogi that the investigation into the processing conditions (soaking and drying) on the functional properties was conducted. This study was undertaken to unravel the unique characteristics of Ogi Powder as may 
be affected by process conditions (soaking and drying temperature). This have the potential of determining possible application of end-product suitability in Ogi powder processing.

\section{Materials and Methodology}

Four maize varieties (A4Y, A5W, S7Y, D1Y) as shown in Table 1 used in this study were obtained from the institute of Agricultural Research and Training in Ibadan, Oyo state. The maize grains were thoroughly cleaned and foreign materials carefully removed. Samples were soaked at varying time of 12, 24 and 36 hours, respectively at a room temperature. This was subsequently decanted and wet milled with attrition milling machine model M230 and sieved with muslin cloth. The water was squeezed out manually and dried at temperature of 40,50 and $60^{\circ} \mathrm{C}$ using Genlab drying cabinet model DC125. The dried samples were pulverized using laboratory mill IKA model M20 and sieved through $212 \mu \mathrm{m}$ mesh. The samples were packaged in polyethylene bag and stored at ambient temperature for further analysis. All the analysis was replicated and data obtained were subjected to statistical analysis.

Table 1. Codes four varieties of maize

\begin{tabular}{ll}
\hline & \\
A4Y & ART/98/SW1- Y \\
A5W & ART/98/SW5 - OB -W \\
S7Y & SUWAN 1 SR. Y \\
D1Y & DMR LSR. Y \\
\hline
\end{tabular}

\subsection{Determination of Moisture Content}

Two gram (2g) of each sample was measured into a previously weight crucible and transferred into the oven set at $105^{\circ} \mathrm{C}$ to dry over overnight. The crucible plus sample was removed from the oven and transferred into desiccators cooled for 60 minutes and weighed (AOAC, 2005). The moisture content was computed using standard mathematical relationship.

\subsubsection{Bulk Density (BD)}

The procedure of Narayana and Narasinga, (1984) was used with slight modification. A specified amount of the powdered Ogi was put into an already weighed (W) $25 \mathrm{ml}$ measuring cylinder, it was gently tapped and the volume was noted. The new level of sample on measuring cylinder was recorded in $\mathrm{ml}$ as $(\mathrm{M})$. The bulk density was computed as shown in Equation (1)

$$
B U L K D E N S I T Y=\frac{W}{M}
$$

\subsubsection{Water and Oil Absorption Capacity (WAC and OAC)}

The water absorption capacity of each Ogi flour sample was determined using the method of Sathe et al., (1982). A suspension of $1 \mathrm{~g}$ of powdered Ogi (db) in $10 \mathrm{ml}$ of distilled water or $[10 \mathrm{ml}$ of executive chef oil with density of $0.92 \mathrm{~g} / \mathrm{ml}$. The suspensions were stirred for 5 minutes using magnetic stirrer (staurt co ltd 7664) at 1000rpm. The mixture was then transferred into centrifuge (CENCOM SELECTA) for 30 minutes at 3500rpm. The free water or oil obtained was removed carefully and the volume of the water /oil was determined. The water or oil absorbed by the powdered Ogi was calculated as the difference between the initial water/oil used and the volume of the supernatant obtained after centrifuging. The result was expressed as a gram of water or oil absorbed per gram of sample.

\subsubsection{Sedimentation Volume}

Sedimentation volume was determined according to the procedure of Raja et al. (1987). A $10 \mathrm{~g}$ (db) of Ogi powdered was weighted into a graduated $100 \mathrm{ml}$ measuring cylinder followed by addition of $100 \mathrm{ml}$ distilled water. The content was mixed thoroughly. The sediment volume was recorded after 3 hours when the level became constant.

\subsubsection{Swelling Power and Starch Solubility}

The swelling power and solubility of the Ogi samples were determined using the method reported by Leach et al. (1959). A 1g of Ogi powered (db) was weighed into centrifuge tube and $50 \mathrm{ml}$ distilled water was added. These tubes were immersed in water bath at temperature range from 50 to $90{ }^{\circ} \mathrm{C}$ at $10{ }^{\circ} \mathrm{C}$ intervals for 30 minutes, thoroughly and constantly stirred with glass rod during the heating period. The tubes were removed, cooled to room temperature and centrifuged at 5000 rpm for 15 minutes. The supernatant was fully transferred into a conical flask and $5 \mathrm{ml}$ was pipetted into a weighed petri dish, evaporated over a steam bath and dried in the air oven at $105^{\circ} \mathrm{C}$ for 4 hours. The weight of the pastes were determined and used to calculate the swelling power as gram of sediment paste per gram starch. Percentage solubility was calculated as gram of soluble starch per gram starch.

\subsection{Viscosity Measurement}

The viscosity of different Ogi powder samples with control were measured in triplicates at controlled temperature of $80^{\circ} \mathrm{C}$ for hot paste and $30^{\circ} \mathrm{C}$ for the cold paste using a digital rotational Brookfield viscometer (Brookfield Viscometer DV-11+Pro, RVDV-11+P Model). Their readings were taken after 1 min rotation at speed (100 rpm). Spindle \#4 hot paste and \#6 for cold paste was used for all measurements. A $600 \mathrm{ml}$ beaker was used for the measurement with the viscometer guard leg on. The samples were poured into the beaker to reach a level that covers the immersion groove on the spindle shaft. All viscosity measurements were carried out immediately after preparing the Ogi powder.

\subsubsection{Least Gelation Concentration}

The method of Coffman and Garcia (1977) was used. Appropriate sample suspensions of 2, 4, 6, 8, 10, 12, 14, $16,18 \%(\mathrm{~m} / \mathrm{v})$ were prepared in $5 \mathrm{~cm}^{3}$ distilled water. The test tube containing these suspensions were heated for 1 hour in boiling water followed by rapid cooling using chilled water at $4^{\circ} \mathrm{C}$ for 1 hour. The least gelation concentration was taken as the concentration when the sample from inverted test tube did not fall down or slip.

\subsubsection{Starch Damage}

One gram of Ogi powder was weighed and placed in the SDmatic spoon. A 3 grams each of boric acid $\left(\mathrm{H}_{3} \mathrm{BO}_{3}\right)$ 
and potassium iodide (KI) and 1 drop of sodium thiosulphate $\left(\mathrm{Na}_{2} \mathrm{O}_{3} \mathrm{~S}_{2}\right)$ at $0.1 \mathrm{~mol} / \mathrm{l}$ were prepared in a plastic bowl and then pour into SDmatic reaction bowl. The moisture and protein content of sample were input into the equipment before the test cycle initiated. Readings were taken after the test cycle is completed and results were recorded (AACC, 2005).

\section{Statistical Analysis}

All determinations of this research work were carried out in triplicates; errors were calculated as standard errors from the mean. The data obtained were subjected to statistical analysis and analysis of variance was determined using SPSS16. Where significant difference $(p<0.05)$ existed, means were separated using Duncan's multiple range tests..
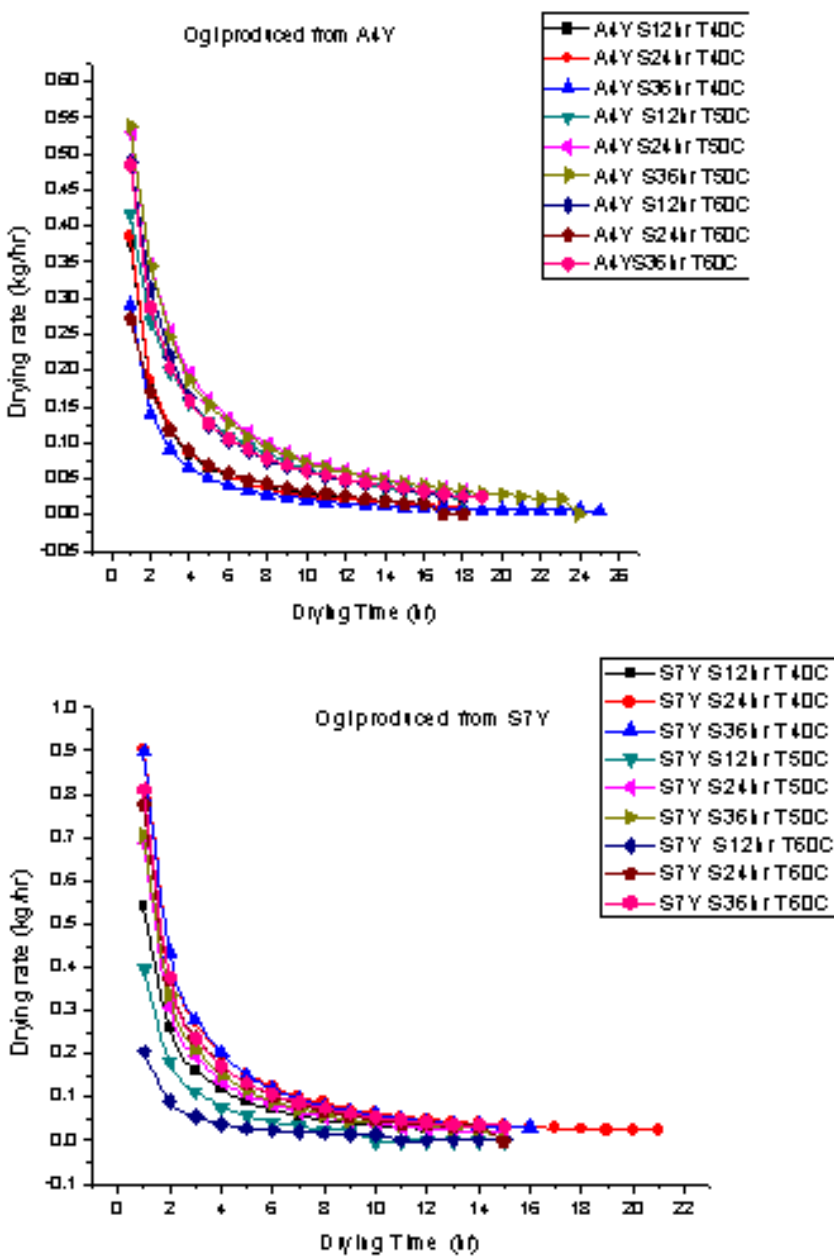

\section{Results and Discussion}

The moisture content of the Ogi produced from the four varieties of maize decreased significantly $(p<0.05)$ with increase in drying time. The results revealed that there was significant decrease in moisture content with increase in the drying tempertaure. The decrease in moisture content and drying rate (Figure 1) were non linear with increase in the drying period and Drying temperature. This may be connected with the migration of water within the Ogi and evaporation of moisture from Ogi into the air. It was observed that the total drying time decreased with increase drying temperature. Similar results have been reported in the literature for various fruits and vegetables such as Sacilik et al. (2005) for organic tomato and Yaldiz et al. (2001) for sultana grapes.
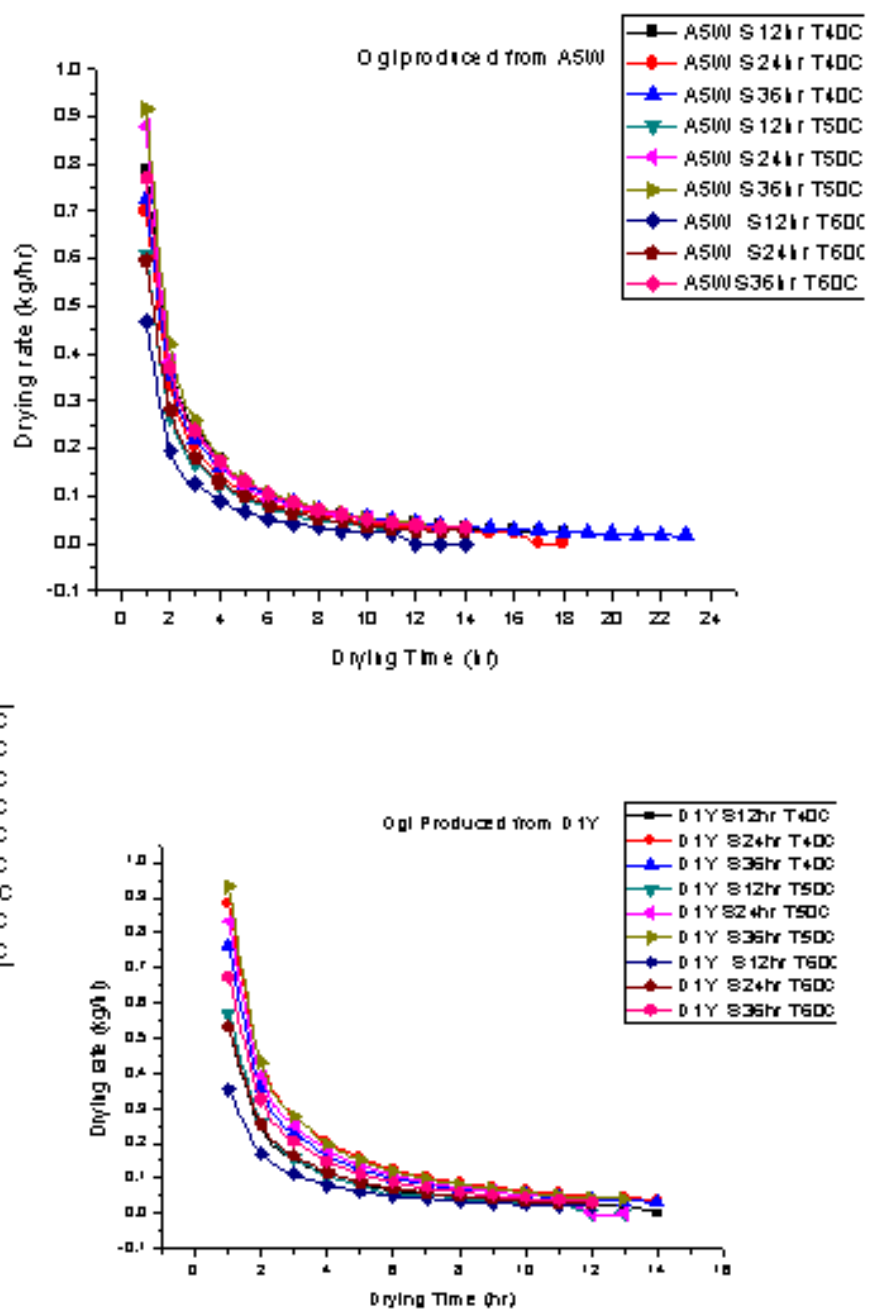

Figure 1. Drying rate of Ogi produced from four varieties of maize and dried at varying temperature

\subsection{Bulk Density}

The bulk density of Ogi powders from the maize varieties is as shown in Table 2 . The value ranged between 0.625 and $0.678 \mathrm{~g} / \mathrm{ml}$ with mean values of $0.6684 \mathrm{~g} / \mathrm{ml}, 0.6377 \mathrm{~g} / \mathrm{ml}, 0.6651 \mathrm{~g} / \mathrm{ml}$ and $0.6569 \mathrm{~g} / \mathrm{ml}$ for A5W, A4Y, D1Y and S7Y, respectively. These were comparable with the values reported by (Okoruwa, 1997; Edema, 1998; Adegunwa et al., 2011) however lower compared to durum wheat blends (Amajeet et al., 1993). The bulk density values were functions of both the density of powder particles and the spatial arrangement of particles in the powder bed (International pharmacopeia, 2012).) The decrease in bulk density may help in reduction of transportation and packaging cost. According to this research work, soaking period and drying time did not indicate any significant effect on the bulk densities of the Ogi powders and there was no significant difference $(p<0.05)$ in the bulk densities. 
Table 2. Effect of soaking time and drying temperature on some functional properties Ogi

\begin{tabular}{|c|c|c|c|c|c|c|}
\hline sample & $\begin{array}{l}\text { soaking Time } \\
\text { (hour) }\end{array}$ & $\begin{array}{c}\text { Drying Temperature } \\
\left({ }^{\circ} \mathrm{C}\right)\end{array}$ & $\begin{array}{l}\text { Bulk density } \\
(\mathrm{g} / \mathrm{ml})\end{array}$ & $\begin{array}{l}\text { sedimentation volume } \\
(\mathrm{ml})\end{array}$ & $\begin{array}{c}\text { Water absorption } \\
\text { capacity }(\mathrm{g} / \mathrm{g})\end{array}$ & Oil Absorption capacity(g/g) \\
\hline \multirow[t]{9}{*}{$\mathrm{A} 4 \mathrm{Y}$} & 12 & 40 & $0.635^{\mathrm{a}}$ & $30^{c}$ & $2.0^{\mathrm{b}}$ & 0.8 \\
\hline & & 50 & $0.635^{\mathrm{a}}$ & $31^{\mathrm{c}}$ & $2.75^{\mathrm{c}}$ & 0.92 \\
\hline & & 60 & $0.646^{\mathrm{a}}$ & $30^{\mathrm{c}}$ & $2.0^{\mathrm{ab}}$ & 1.0 \\
\hline & 24 & 40 & $0.625^{\mathrm{a}}$ & $30^{c}$ & $2.5^{\mathrm{b}}$ & 0.81 \\
\hline & & 50 & $0.625^{\mathrm{a}}$ & $31^{\mathrm{c}}$ & $2.25^{\mathrm{b}}$ & 0.81 \\
\hline & & 60 & $0.625^{a}$ & $29^{\mathrm{bc}}$ & 1.5 & 0.94 \\
\hline & 36 & 40 & $0.646^{\mathrm{ab}}$ & $30^{c}$ & 2.25 & 0.82 \\
\hline & & 50 & $0.646^{\mathrm{ab}}$ & $31^{c}$ & $2.0^{\mathrm{b}}$ & 0.8 \\
\hline & & 60 & $0.646^{\mathrm{ab}}$ & $29^{\mathrm{bc}}$ & $1.0^{\mathrm{a}}$ & 0.94 \\
\hline \multirow[t]{8}{*}{ A5W } & 12 & 40 & $0.667^{\mathrm{b}}$ & $30^{c}$ & $1.0^{\mathrm{a}}$ & 0.87 \\
\hline & & 50 & $0.667^{\mathrm{b}}$ & $28^{\mathrm{ab}}$ & $1.25^{\mathrm{ab}}$ & 0.89 \\
\hline & & 60 & $0.667^{\mathrm{b}}$ & $28^{\mathrm{ab}}$ & $1.5^{\mathrm{ab}}$ & 1.01 \\
\hline & 24 & 40 & $0.667^{b}$ & $27^{\mathrm{a}}$ & $1.0^{\mathrm{a}}$ & 1.0 \\
\hline & & 60 & $0.667^{\mathrm{b}}$ & $29^{\mathrm{bc}}$ & $1.5^{\mathrm{ab}}$ & 1.0 \\
\hline & 36 & 40 & $0.636^{\mathrm{a}}$ & $28^{\mathrm{ab}}$ & $1.25^{\mathrm{ab}}$ & 0.86 \\
\hline & & 50 & $0.657_{\mathrm{ab}}$ & $30^{c}$ & $1.5^{\mathrm{ab}}$ & 0.82 \\
\hline & & 60 & $0.679^{b}$ & $28^{\mathrm{ab}}$ & $1.0^{\mathrm{a}}$ & 0.89 \\
\hline \multirow[t]{9}{*}{ S7Y } & 12 & 40 & $0.646^{\mathrm{ab}}$ & $28^{\mathrm{ab}}$ & $1.2^{\mathrm{a}}$ & 0.9 \\
\hline & & 50 & $0.667^{\mathrm{b}}$ & $27^{\mathrm{a}}$ & $1.4^{\mathrm{ab}}$ & 0.92 \\
\hline & & 60 & $0.874^{c}$ & $29^{\mathrm{bc}}$ & $1.4^{\mathrm{ab}}$ & 1.05 \\
\hline & 24 & 40 & $0.635^{\mathrm{a}}$ & $28^{\mathrm{ab}}$ & $1.2^{\mathrm{a}}$ & 0.8 \\
\hline & & 50 & $0.655^{\mathrm{ab}}$ & $28^{\mathrm{ab}}$ & $1.2^{\mathrm{a}}$ & 0.84 \\
\hline & & 60 & $0.662^{\mathrm{b}}$ & $29^{\mathrm{bc}}$ & $1.4^{\mathrm{ab}}$ & 0.92 \\
\hline & 36 & 40 & $0.646^{\mathrm{ab}}$ & $29^{\mathrm{bc}}$ & $1.4^{\mathrm{ab}}$ & 0.81 \\
\hline & & 50 & $0.655^{\mathrm{ab}}$ & $28.5^{\mathrm{ab}}$ & $1.2^{\mathrm{ab}}$ & 0.81 \\
\hline & & 60 & $0.667^{b}$ & $29^{\mathrm{ab}}$ & $1.4^{\mathrm{ab}}$ & 0.86 \\
\hline \multirow[t]{8}{*}{ D1Y } & 12 & 40 & $0.657^{\mathrm{ab}}$ & $30^{c}$ & $1.4^{\mathrm{ab}}$ & 0.84 \\
\hline & & 60 & $0.677^{b}$ & $26^{\mathrm{a}}$ & $1.4^{\mathrm{ab}}$ & 1.05 \\
\hline & 24 & 40 & $0.667^{b}$ & $28^{\mathrm{ab}}$ & $1.6^{\mathrm{ab}}$ & 0.81 \\
\hline & & 50 & $0.659^{b}$ & $27^{\mathrm{a}}$ & $1.2^{\mathrm{a}}$ & 0.97 \\
\hline & & 60 & $0.668^{b}$ & $28^{\mathrm{ab}}$ & $1.4^{\mathrm{ab}}$ & 0.99 \\
\hline & 36 & 40 & $0.646^{\mathrm{ab}}$ & $27^{\mathrm{a}}$ & $1.4^{\mathrm{ab}}$ & 0.92 \\
\hline & & 50 & 0.667 & $28^{b}$ & $1.2^{\mathrm{a}}$ & 0.98 \\
\hline & & 60 & 0.678 & $28.5^{\mathrm{ab}}$ & 1.2 & 1 \\
\hline
\end{tabular}

\subsection{Sedimentation}

Sedimentation is an important determinant of cooking quality. This is shown in Table 2. The grains with good hydration and lower cooking time are generally preferred for cooking purposes (Ahenkora et al., 1999). The value ranged between 26 and $31 \mathrm{ml}$. Okaka and Potter, (1979) reported that sedimentation and hydration of maize is influenced by processing methods affecting starch gelatinization and swelling power. However, in the present investigation the same tendency was observed however, there was no significant difference $(\mathrm{p}>0.05)$.

\subsection{Water Absorption Capacity (WAC) and Oil Absorption Capacity (OAC)}

The result for water absorption capacity (WAC) is as shown in Table 2. The results of Water Absorption Capacity (WAC) and Oil absorption capacity of Ogi samples which ranged between $1.0 \mathrm{~g} / \mathrm{g}$ and $2.75 \mathrm{~g} / \mathrm{g}$. There were significant differences $(\mathrm{p}<0.05)$ between the maize varieties. The variations in WAC values also indicated differences in the degree of engagement to form hydrogen and covalent bonds between starch chains and the degree of availability of water binding sites among the starches (Hoover and Sosulski, 1986). Similar results were reported for yellow and white maize varieties (Adegunwa et al., 2011). The water absorption capacity of the Ogi powder gave it an advantage of being used as a thickener in liquid and semi-liquids foods since the flours has the ability to absorb water and swell for improved consistency in food. The observed differences in WAC of the starches might also be due to various factors such as particle size, amylose/amylopectin ratio and molecular structure (Adegunwa et al., 2011). The larger the granular size of powder has may affect the water binding capacity of starches (Akalu et al., 1998).

Oil absorption capacity (OAC) is the ability of the flour protein to physically bind fat by capillary attraction and it is of great importance since fat acts as flavor retainer and increase the mouth feel of foods (Kinsella, 1976). OAC of the Ogi powder ranged between 0.8 to $1.05 \mathrm{~g} / \mathrm{g}$ with significant difference $(\mathrm{p}<0.05)$ among the maize varieties. These values were lower than OAC of taro flours 190\%( Tagodoe and Nip, 1994), lupin seed flour, 167\% (Sathe et al., 1982b). Protein denaturation and dissociation may occur during fermentation which exposes the polar amino acid of the maize proteins thus enhancing hydrophobicity of protein (Vausinas and Nakai, 1983). These observations were consistent with the reports of Sefa-Dedeh et al. (2002 ). There was no clear trends in WAC and OAC values for Ogi powder. However, Ogi 
powder from A4Y soaked for 12 hours exhibited higher WAC values at $50^{\circ} \mathrm{C}$ compared with others.

\subsection{Swelling power and Solubility}

Swelling is a function of ratio of amylose to amylopectin, the characteristics of each fraction in terms of molecular weight - distribution degree length of branching and confirmation (Onitilo, 2007). The results of swelling power and solubility of the Ogi powder at different temperatures are presented in Table 3 and Table 4, respectively. The swelling power of the starches increased with increase in temperature. The swelling power of the Ogi powder at 50,70 and $90^{\circ} \mathrm{C}$ ranged from 2.32 to 3.78 , 7.01- 8.43 and $11.67-14.58 \mathrm{~g} / \mathrm{g}$, respectively. The results were similar to the report by Adebowale et al. (2005) for red sorghum flour and legume starches by Hoover and
Sosulki, (1991). This may have been as a result of fallen gelatinization temperature of Ogi powders. The swelling pattern of the flour suggests the level of crystalline packing of the starch granules (Billiadaris, 1982). This indicated that the swelling power granules reflect the extent of the association forces within the granules. A decrease in solubility was noticed in all samples as the temperature increases. Since leaching of amylose is said to be responsible for most of the solubility of starch based product (Dengate, 1981), higher solubility in S7Y implies that it is greater in leaching than other. According to Numfor et al.(1996), leaching is enhanced by hydrolysis of amylose during soaking or hindered by new internal bounding. Solubility of Ogi powered may be a function of processing and reconstitution. The higher the solubility, the more the Ogi may reconstitute well in water.

Table 3. Effect of soaking time and drying temperature on swelling power Ogi

\begin{tabular}{|c|c|c|c|c|c|c|c|}
\hline \multirow[b]{2}{*}{ SAMPLE } & \multirow[b]{2}{*}{ SOAKING TIME (hrs) } & \multirow[b]{2}{*}{ DRYING TEMPERATURE $\left({ }^{\circ} \mathrm{C}\right)$} & \multirow[b]{2}{*}{$50\left({ }^{\circ} \mathrm{C}\right)$} & \multirow[b]{2}{*}{$60\left({ }^{\circ} \mathrm{C}\right)$} & \multirow[b]{2}{*}{$70\left({ }^{\circ} \mathrm{C}\right)$} & \multicolumn{2}{|c|}{ SWELLING POWER (g/g) } \\
\hline & & & & & & $80\left({ }^{\circ} \mathrm{C}\right)$ & $90\left({ }^{\circ} \mathrm{C}\right)$ \\
\hline \multirow[t]{9}{*}{ A4Y } & $12 / 40 \mathrm{C}$ & 40 & $3.25^{\mathrm{i}}$ & $4.098^{\mathrm{g}}$ & $7.46^{\mathrm{e}}$ & $10.59^{c}$ & 14.579a \\
\hline & & 50 & $3.16^{\mathrm{i}}$ & $4.11^{\mathrm{g}}$ & $6.947^{\mathrm{ef}}$ & $9.342^{\mathrm{d}}$ & $12.498^{\mathrm{bc}}$ \\
\hline & & 60 & $3.12^{\mathrm{i}}$ & $4.13^{g}$ & $8.06^{\mathrm{e}}$ & $9.476^{\mathrm{d}}$ & $11.965^{\mathrm{bc}}$ \\
\hline & 24 & 40 & $2.93^{\mathrm{ij}}$ & $3.87^{\mathrm{gh}}$ & $7.17^{\mathrm{ef}}$ & $9.987^{\mathrm{cd}}$ & $13.59^{\mathrm{a}}$ \\
\hline & & 50 & $2.89^{\mathrm{ij}}$ & $3.98^{\text {gh }}$ & $7.232^{\mathrm{e}}$ & $10.07^{\mathrm{dc}}$ & $14.269^{\mathrm{a}}$ \\
\hline & & 60 & $3.26^{\mathrm{i}}$ & $4.49^{\mathrm{g}}$ & $7.213^{\mathrm{e}}$ & $9.332^{\mathrm{d}}$ & $11.037^{\mathrm{bc}}$ \\
\hline & 36 & 40 & $2.546^{\mathrm{ij}}$ & $3.99^{\text {gh }}$ & $7.29^{\mathrm{e}}$ & $9.287^{\mathrm{d}}$ & $13.709^{\mathrm{ab}}$ \\
\hline & & 50 & $2.591^{\mathrm{ij}}$ & $4.10^{\mathrm{gh}}$ & $7.625^{e}$ & $10.49^{\mathrm{bc}}$ & $15.29^{\mathrm{a}}$ \\
\hline & & 60 & $3.097^{\mathrm{i}}$ & $4.12^{\mathrm{g}}$ & $7.955^{\mathrm{e}}$ & $9.765^{\mathrm{d}}$ & $12.42^{b}$ \\
\hline \multirow[t]{9}{*}{ A5W } & 12 & 40 & $3.275^{\mathrm{i}}$ & $4.32^{\mathrm{g}}$ & $8.43^{\mathrm{de}}$ & $9.52^{\mathrm{d}}$ & $12.35^{b}$ \\
\hline & & 50 & $3.459^{\mathrm{i}}$ & $3.26^{\mathrm{i}}$ & $7.08^{\mathrm{ef}}$ & $9.56^{\mathrm{d}}$ & $12.56^{b}$ \\
\hline & & 60 & $2.876^{\mathrm{ij}}$ & $3.25^{\mathrm{i}}$ & $7.01^{\mathrm{ef}}$ & $9.19^{\mathrm{de}}$ & $12.48^{b}$ \\
\hline & 24 & 40 & $3.098^{\mathrm{i}}$ & $3.83^{g g}$ & $8.06^{\mathrm{e}}$ & $9.67^{d}$ & $12.25^{b}$ \\
\hline & & 50 & $2.852^{\mathrm{ij}}$ & $3.15^{\mathrm{hi}}$ & $7.03^{\mathrm{ef}}$ & $9.73^{d}$ & $12.8^{\mathrm{b}}$ \\
\hline & & 60 & $2.99^{\mathrm{i}}$ & $3.149^{\mathrm{hi}}$ & $7.21^{\mathrm{e}}$ & $9.99^{\mathrm{dc}}$ & $13.39^{\mathrm{ab}}$ \\
\hline & 36 & 40 & $3.034^{\mathrm{i}}$ & $3.96^{\mathrm{gh}}$ & $8.04^{e}$ & 9.326 & $12.749^{b}$ \\
\hline & & 50 & $3.301^{\mathrm{i}}$ & $3.02^{\mathrm{hi}}$ & $7.08^{\text {ef }}$ & $8.981^{\text {de }}$ & $12.15^{b}$ \\
\hline & & 60 & $3.272^{\mathrm{i}}$ & $3.03^{\text {hi }}$ & $7.26^{\mathrm{e}}$ & $9.378^{d}$ & $12.47^{b}$ \\
\hline \multirow[t]{9}{*}{ S7Y } & 12 & 40 & $3.223^{\mathrm{i}}$ & $4.09^{g}$ & $7.46^{\mathrm{e}}$ & $10.35^{c}$ & $14.57^{\mathrm{a}}$ \\
\hline & & 50 & $3.235^{\mathrm{i}}$ & $4.11^{\mathrm{g}}$ & $6.95^{\mathrm{ef}}$ & $9.663^{d}$ & $12.47^{b}$ \\
\hline & & 60 & $3.12^{\mathrm{i}}$ & $4.12^{\mathrm{g}}$ & $8.06^{\mathrm{e}}$ & $9.482^{\mathrm{d}}$ & $11.99^{\mathrm{bc}}$ \\
\hline & 24 & 40 & $3.128^{\mathrm{i}}$ & $3.87^{\text {gh }}$ & $7.18^{\mathrm{ef}}$ & $9.978^{\mathrm{d}}$ & $13.59^{\mathrm{ab}}$ \\
\hline & & 50 & $2.89^{\mathrm{ij}}$ & $3.982^{\mathrm{g}}$ & $7.23^{\mathrm{e}}$ & $10.01^{\mathrm{cd}}$ & $14.24^{\mathrm{ab}}$ \\
\hline & & 60 & $3.26^{\mathrm{i}}$ & $4.49^{g}$ & $7.21^{\mathrm{e}}$ & $9.39^{d}$ & $11.67^{\mathrm{bc}}$ \\
\hline & 36 & 40 & $2.443^{\mathrm{k}}$ & $3.95^{\mathrm{g}}$ & $7.93^{\mathrm{e}}$ & $9.322^{d}$ & $13.687^{\mathrm{ab}}$ \\
\hline & & 50 & $2.321^{\mathrm{k}}$ & $4.10^{g}$ & $7.61^{\mathrm{e}}$ & $10.41^{\mathrm{d}}$ & $15.40^{\mathrm{a}}$ \\
\hline & & 60 & $3.216^{\mathrm{i}}$ & $4.12^{\mathrm{g}}$ & $7.89^{e}$ & $9.76^{\mathrm{d}}$ & $12.248^{b}$ \\
\hline \multirow[t]{9}{*}{ D1Y } & 12 & 40 & $3.275^{\mathrm{i}}$ & $4.326^{\mathrm{g}}$ & $8.43^{\mathrm{e}}$ & $9.45^{\mathrm{d}}$ & $12.36^{\mathrm{b}}$ \\
\hline & & 50 & $3.459^{\mathrm{i}}$ & $3.262^{\mathrm{i}}$ & $7.01^{\mathrm{ef}}$ & $9.53^{d}$ & $12.53^{b}$ \\
\hline & & 60 & $2.876^{\mathrm{ij}}$ & $3.515^{\text {hi }}$ & $7.22^{\mathrm{e}}$ & $9.36^{\mathrm{d}}$ & $12.51^{\mathrm{b}}$ \\
\hline & 24 & 40 & $3.098^{\mathrm{i}}$ & $3.654^{\mathrm{hi}}$ & $8.06^{\mathrm{e}}$ & $9.67^{d}$ & $12.33^{\mathrm{b}}$ \\
\hline & & 50 & $2.857^{\mathrm{ij}}$ & $3.059^{\mathrm{i}}$ & $7.04^{\mathrm{ef}}$ & $9.72^{\mathrm{d}}$ & $12.51^{\mathrm{b}}$ \\
\hline & & 60 & $2.99^{\mathrm{ij}}$ & $3.13^{\mathrm{i}}$ & $7.413^{\mathrm{e}}$ & $9.94^{\mathrm{cd}}$ & $13.13^{b}$ \\
\hline & 36 & 40 & $3.784^{\mathrm{hi}}$ & $4.16^{g}$ & $8.034^{\mathrm{e}}$ & $9.42^{\mathrm{d}}$ & $12.67^{\mathrm{b}}$ \\
\hline & & 50 & $3.301^{\mathrm{i}}$ & $3.02^{\mathrm{i}}$ & $7.734^{\mathrm{e}}$ & $8.951^{d}$ & $12.25^{b}$ \\
\hline & & 60 & $3.27^{\mathrm{i}}$ & $3.03^{i}$ & $7.204^{\mathrm{e}}$ & $9.376^{\mathrm{d}}$ & $11.98^{\mathrm{bc}}$ \\
\hline
\end{tabular}

According to Osungbaro (1990a), the degree of swelling and amount of soluble components depends on the type and species of starch in the flour samples. According to Hoover and Martin (1991) and Hoover and Maunal (1996), increase in temperature may allow amylose (water soluble fraction) molecules located in the bulk amorphous regions to interact with the branched segment of amylopectin (water-insoluble fraction) in the crystalline regions and thereby weakens the starch granules of flour leading to improved solubility. The solubility of Ogi powders decreased consistently with increase in temperatures. The decrease in solubility was highest at $90^{\circ} \mathrm{C}$. This may be due to the effect of swelling which has form matrixes around the leached amylase (Hoover and Martin, 1991). The differences among the Ogi powder samples in their swelling and solubility patterns can form the basis of the functional properties that determine their suitability in product development. 
Table 4. Effect of soaking time and drying temperature on Solubility of Ogi

\begin{tabular}{|c|c|c|c|c|c|c|c|}
\hline & & & & & & \multicolumn{2}{|c|}{ SOLUBILITY (g/g) } \\
\hline SAMPLE & SOAKING TIME (hrs) & DRYING TEMPERATURE $\left({ }^{\circ} \mathrm{C}\right)$ & $50\left({ }^{\circ} \mathrm{C}\right)$ & $60\left({ }^{\circ} \mathrm{C}\right)$ & $70\left({ }^{\circ} \mathrm{C}\right)$ & $80\left({ }^{\circ} \mathrm{C}\right)$ & $90\left({ }^{\circ} \mathrm{C}\right)$ \\
\hline \multirow[t]{9}{*}{$\mathrm{A} 4 \mathrm{Y}$} & 12 & 40 & $0.235^{d}$ & $0.101^{\mathrm{c}}$ & $0.073^{\mathrm{cb}}$ & $0.054^{\mathrm{a}}$ & $0.038^{\mathrm{a}}$ \\
\hline & & 50 & $0.253^{d}$ & $0.214^{\mathrm{d}}$ & $0.103^{\text {bc }}$ & $0.099^{\mathrm{ab}}$ & $0.019^{\mathrm{a}}$ \\
\hline & & 60 & $0.22^{\mathrm{d}}$ & $0.215^{\mathrm{d}}$ & $0.198^{\mathrm{cd}}$ & 0.045 & $0.087^{\mathrm{ab}}$ \\
\hline & 24 & 40 & $0.248^{d}$ & $0.223^{\mathrm{d}}$ & $0.183^{c}$ & 0.067 & $0.066^{\mathrm{ab}}$ \\
\hline & & 50 & $0.249^{\mathrm{d}}$ & $0.198^{\mathrm{cd}}$ & $0.172^{\mathrm{c}}$ & 0.09 & $0.036^{\mathrm{a}}$ \\
\hline & & 60 & $0.196^{\mathrm{cd}}$ & $0.243^{d}$ & $0.11^{\mathrm{c}}$ & 0.076 & $0.022^{\mathrm{a}}$ \\
\hline & 36 & 40 & $0.349^{f}$ & $0.277^{\mathrm{e}}$ & $0.154^{\mathrm{c}}$ & 0.052 & $0.022^{\mathrm{a}}$ \\
\hline & & 50 & $0.219^{d}$ & $0.1^{\mathrm{ab}}$ & 0.063 & 0.057 & $0.02^{\mathrm{a}}$ \\
\hline & & 60 & $0.216^{\mathrm{d}}$ & $0.209^{d}$ & $0.181^{\mathrm{c}}$ & 0.087 & $0.031^{\mathrm{a}}$ \\
\hline \multirow[t]{9}{*}{ A5W } & 12 & 40 & $0.206^{\mathrm{cd}}$ & $0.197^{\mathrm{cd}}$ & $0.165^{c}$ & $0.088^{\mathrm{ab}}$ & $0.033^{\mathrm{a}}$ \\
\hline & & 50 & $0.302^{\mathrm{ef}}$ & $0.217^{\mathrm{d}}$ & $0.133^{c}$ & $0.088^{\mathrm{ab}}$ & $0.015^{\mathrm{a}}$ \\
\hline & & 60 & $0.502^{\mathrm{h}}$ & $0.226^{d}$ & $0.158^{c}$ & $0.072^{\mathrm{ab}}$ & $0.022^{\mathrm{a}}$ \\
\hline & 24 & 40 & $0.383^{\mathrm{e}}$ & $0.339^{\mathrm{e}}$ & $0.161^{\mathrm{c}}$ & $0.078^{\mathrm{ab}}$ & $0.022^{\mathrm{a}}$ \\
\hline & & 50 & $0.529^{\mathrm{g}}$ & $0.206^{\mathrm{cd}}$ & $0.153^{c}$ & $0.076^{\mathrm{ab}}$ & $0.022^{\mathrm{a}}$ \\
\hline & & 60 & $0.429^{\mathrm{g}}$ & 0.222 & 0.143 & $0.056^{\mathrm{a}}$ & $0.020^{\mathrm{a}}$ \\
\hline & 36 & 40 & $0.207^{d}$ & $0.287^{\mathrm{d}}$ & $0.172^{\mathrm{c}}$ & $0.091^{b c}$ & $0.051^{\mathrm{a}}$ \\
\hline & & 50 & $0.301^{\mathrm{e}}$ & $0.215^{\mathrm{cd}}$ & 0.209 & $0.10^{\mathrm{c}}$ & $0.043^{\mathrm{a}}$ \\
\hline & & 60 & $0.301^{\mathrm{e}}$ & $0.198^{\mathrm{cd}}$ & $0.153^{c}$ & 0.089 & $0.041^{a}$ \\
\hline \multirow[t]{9}{*}{ S7Y } & 12 & 40 & $0.204^{\mathrm{d}}$ & $0.20^{\text {cd }}$ & $0.122^{\mathrm{c}}$ & $0.045^{\mathrm{a}}$ & 0.01 \\
\hline & & 50 & $0.387^{f}$ & $0.311^{\mathrm{e}}$ & $0.219^{\text {cd }}$ & $0.115^{c}$ & 0.078 \\
\hline & & 60 & $0.396^{f}$ & $0.302^{\mathrm{e}}$ & $0.279^{d}$ & $0.162^{c}$ & 0.045 \\
\hline & 24 & 40 & $0.194^{\mathrm{cd}}$ & $0.123^{\mathrm{cd}}$ & $0.102^{b c}$ & $0.079^{\mathrm{ab}}$ & 0.066 \\
\hline & & 50 & $0.387^{f}$ & $0.289^{d}$ & $0.199^{\mathrm{cd}}$ & $0.103^{\mathrm{cb}}$ & 0.055 \\
\hline & & 60 & $0.437^{f}$ & $0.314^{\mathrm{e}}$ & $0.238^{\mathrm{cd}}$ & $0.178^{c}$ & 0.067 \\
\hline & 36 & 40 & $0.437^{f}$ & $0.332^{\mathrm{e}}$ & 0.294 & $0.162^{c}$ & 0.043 \\
\hline & & 50 & $0.289^{\mathrm{e}}$ & $0.26^{\mathrm{d}}$ & $0.188^{\text {cd }}$ & $0.122^{c}$ & 0.054 \\
\hline & & 60 & $0.435^{\mathrm{f}}$ & $0.376^{\mathrm{e}}$ & $0.211^{\mathrm{cd}}$ & $0.156^{c}$ & 0.099 \\
\hline \multirow[t]{9}{*}{ D1Y } & 12 & 40 & $0.447^{\mathrm{g}}$ & $0.382^{\mathrm{e}}$ & $0.265 c$ & $0.117^{c}$ & $0.045 a$ \\
\hline & & 50 & $0.387^{\mathrm{e}}$ & $0.321^{\mathrm{e}}$ & 0.26 & $0.125^{c}$ & $0.067^{\mathrm{ab}}$ \\
\hline & & 60 & $0.512^{\mathrm{g}}$ & $0.399^{\text {ef }}$ & 0.302 & $0.198^{\mathrm{cd}}$ & $0.094^{\mathrm{a}}$ \\
\hline & 24 & 40 & $0.437^{\mathrm{f}}$ & $0.323^{\mathrm{e}}$ & 0.285 & $0.166^{c}$ & $0.073^{\mathrm{a}}$ \\
\hline & & 50 & $0.204^{\text {cd }}$ & $0.201^{\mathrm{c}}$ & $0.155^{\mathrm{c}}$ & $0.077^{b}$ & $0.052^{\mathrm{a}}$ \\
\hline & & 60 & $0.467^{\mathrm{g}}$ & $0.379^{\mathrm{e}}$ & 0.234 & $0.10^{\mathrm{d}}$ & $0.057^{\mathrm{a}}$ \\
\hline & 36 & 40 & $0.346^{\mathrm{e}}$ & $0.292^{\mathrm{d}}$ & 0.201 & $0.096^{\mathrm{b}}$ & $0.086^{\mathrm{ab}}$ \\
\hline & & 50 & $0.294^{\mathrm{d}}$ & 0.271 & $0.199^{\text {cd }}$ & $0.078^{b}$ & $0.055^{\mathrm{ab}}$ \\
\hline & & 60 & $0.387^{\mathrm{e}}$ & $0.288^{d}$ & 0.255 & $0.167^{\mathrm{c}}$ & $0.097^{\mathrm{ab}}$ \\
\hline
\end{tabular}

Table 5. Effect of soaking time and drying temperature on Viscosity and starch Damage of Ogi

\begin{tabular}{|c|c|c|c|c|c|}
\hline \multirow[b]{2}{*}{ SAMPLE } & \multirow[b]{2}{*}{ SOAKING TIME (hrs) } & \multirow[b]{2}{*}{ DRYING TEMPERATURE $\left({ }^{\circ} \mathrm{C}\right)$} & \multicolumn{2}{|c|}{ VISCOSITY (CPS) } & \multirow{2}{*}{ DAMAGE STARCH (AI \%) } \\
\hline & & & $\mathbf{8 0}^{\circ} \mathrm{C}$ & $30^{\circ} \mathrm{C}$ & \\
\hline \multirow[t]{9}{*}{$\mathrm{A} 4 \mathrm{Y}$} & 12 & 40 & $1781^{\mathrm{a}}$ & $1540^{\mathrm{d}}$ & 92.55 \\
\hline & & 50 & $1421^{\mathrm{f}}$ & $1110^{\mathrm{k}}$ & 94.05 \\
\hline & & 60 & $1262^{\mathrm{i}}$ & $865^{\mathrm{d}}$ & 95.02 \\
\hline & 24 & 40 & $1743^{\mathrm{b}}$ & $1590^{\mathrm{d}}$ & 92.03 \\
\hline & & 50 & $1231^{\mathrm{j}}$ & $984^{1}$ & 94.17 \\
\hline & & 60 & $1462^{\mathrm{e}}$ & $786^{\mathrm{p}}$ & 94.76 \\
\hline & 36 & 40 & $1782^{\mathrm{a}}$ & $1470^{f}$ & 92.11 \\
\hline & & 50 & $1335^{\mathrm{h}}$ & $1192^{\text {cd }}$ & 93.21 \\
\hline & & 60 & $1254^{\mathrm{h}}$ & $950^{\mathrm{m}}$ & 93.53 \\
\hline \multirow[t]{9}{*}{ A5W } & 12 & 40 & $1778^{\mathrm{a}}$ & $1303^{\mathrm{c}}$ & 93.01 \\
\hline & & 50 & $1370^{\mathrm{g}}$ & $1225^{\mathrm{h}}$ & 93.63 \\
\hline & & 60 & $1282^{\mathrm{h}}$ & $725^{q}$ & 94.50 \\
\hline & 24 & 40 & $1794^{\mathrm{a}}$ & $1310^{\mathrm{h}}$ & 92.93 \\
\hline & & 50 & $1760^{\mathrm{a}}$ & $1110^{\mathrm{k}}$ & 93.41 \\
\hline & & 60 & $1420^{\mathrm{f}}$ & $804^{\mathrm{n}}$ & 94.44 \\
\hline & 36 & 40 & $1773^{\mathrm{a}}$ & $1519^{d}$ & 92.35 \\
\hline & & 50 & $1739^{\mathrm{b}}$ & $1032^{1}$ & 92.59 \\
\hline & & 60 & 1392 & $810^{\circ}$ & 93.27 \\
\hline \multirow[t]{9}{*}{ S7Y } & 12 & 40 & $1750^{c}$ & $1444^{\mathrm{f}}$ & 92.41 \\
\hline & & 50 & $1484^{\mathrm{e}}$ & $1102^{k}$ & 93.12 \\
\hline & & 60 & $1273^{j}$ & $982^{1}$ & 93.78 \\
\hline & 24 & 40 & $1770^{\mathrm{b}}$ & $130 \mathrm{~g}$ & 91.87 \\
\hline & & 50 & $1450^{\mathrm{f}}$ & $1176^{\mathrm{j}}$ & 93.01 \\
\hline & & 60 & $1235^{j}$ & $1003^{\mathrm{m}}$ & 94.54 \\
\hline & 36 & 40 & $1792^{\mathrm{a}}$ & $1572^{\mathrm{b}}$ & 92.85 \\
\hline & & 50 & $1498^{\mathrm{e}}$ & $1109^{\text {cd }}$ & 93.46 \\
\hline & & 60 & $1258^{\mathrm{i}}$ & $879^{n}$ & 93.89 \\
\hline \multirow[t]{9}{*}{ D1Y } & 12 & 40 & $1763^{\mathrm{b}}$ & $1486^{\mathrm{b}}$ & 92.16 \\
\hline & & 50 & $1403^{f}$ & $1039^{\mathrm{cd}}$ & 94.22 \\
\hline & & 60 & $1226^{\mathrm{g}}$ & $892^{\mathrm{d}}$ & 94.07 \\
\hline & 24 & 40 & $1801^{\mathrm{a}}$ & $1600^{\mathrm{C}}$ & 92.48 \\
\hline & & 50 & $1457^{\mathrm{f}}$ & $1251^{\mathrm{i}}$ & 94.42 \\
\hline & & 60 & $1277^{\mathrm{h}}$ & $1068^{\mathrm{m}}$ & 94.23 \\
\hline & 36 & 40 & $1756^{\mathrm{b}}$ & $1472^{f}$ & 92.32 \\
\hline & & 50 & $1433^{f}$ & $1126^{\mathrm{ck}}$ & 93.56 \\
\hline & & 60 & $1200 \mathrm{j}$ & $978^{\mathrm{m}}$ & 93.67 \\
\hline
\end{tabular}


The viscosity and starch damage values of the Ogi powder from all the maize varieties pastes is as shown in Table 5 and this ranged from 1200-1794 cps, and 8041540 at 80 and $30{ }^{\circ} \mathrm{C}$, respectively. The viscosity values of Ogi powder pastes were lower when compared with those of sweet potato and cocoyam starch pastes (Peroni et al., 2006). Ogi powder from S7Y and A5W exhibited higher paste viscosity at $80{ }^{\circ} \mathrm{C}$ than their corresponding $\mathrm{A} 4 \mathrm{Y}$ and D1Y. There was significant difference $(p<0.05)$ in the viscosity of the Ogi powder at both temperature of measurement and soaking time. The viscosity of Ogi powders from S7Y and A5W were similar to those Okoruwa et al. (1995) and Fasasi et al.(2005). The differences observed in the viscosities of the Ogi powder may be attributed to different rates of water absorption and swelling of starch granules of these flours during heating (Ragaee and Abdel-Aal, 2006). Retrogradation properties of starch paste are often related to the structures of amylose and amylopectin (Peroni et al., 2006; Gudmundsson, 1994). Lower degree of retrogradation may be attributed to higher content of short branches of amylopectin chains and long amylose molecules (Spence and Jane, 1999). According to Sasaki, 2005 retrogradation is a function of strong or weaker crystallinity. Among the Ogi powders, A5W and S7Y which exhibited higher viscosities also, displayed the highest degree of retrogradation (1212cps and 1174cps, respectively). There was no significant differences $(p>0.05)$ on the levels of retrogradation for maize varieties. Peroni et al. (2006) reported higher levels of retrogradation for ginger and yam starch, canna, sweet potato, arrowroot and cassava starches. The retrograded Ogi powders in this study were within the reported range by Okoruwa et a. (1995), Edema (2005) and Fasasi et al. (2008). The greater degree of retrogradation in tubers could be attributed to higher contents of short amylopectin branches (Shi and Seib, 1992; Spence and Jane, 1999) unlike the cereals. It was well established that starches with higher enthalpies of gelatinization exhibit lower levels of retrogradation and vice versa.

\subsection{Starch Damage}

The results showed that the percentage absorbed iodine were high in all varieties irrespective of the soaking time and drying temperature and were above 90\% which indicated higher degree of starch damage in all the Ogi powders. The starch damage of the Ogi powders varies from 92.03 to $95.02 \%$. The results obtained were higher than those reported by Bolade (2010), who reported starch damage range of 11.3 to $13.9 \%$ for some maize varieties. It was also higher than the starch damage between 73.5 and $75.8 \%$ reported by Faridi (1990). The difference in the results may be due to the method in the determination of starch damage. The variation in the damaged starch values of flours from different maize varieties indicated that different maize types could respond differently to the same milling operational procedures. This may be attributed to genetic make-up of endosperm of each maize variety as the bond strength, the starch granules and the embedding protein matrix within the endosperm. This determine varying resistances during milling (Bolade, 2010; Faridi, 1990). The degree of maize kernel hardness is another factor that may be responsible for damaged starch variation in the flours (Faridi, 1990). Faridi (1990) observed that the variation in the damaged starch value of cereal flour was dependent on the severity of the milling process and the hardness of the cereal kernel.

\section{Conclusion}

The bulk densities and Sedimentation volumes of the Ogi powders were not influenced by processing methods. Water absorption capacity of some Ogi powder significantly increased after drying and increased with increase in temperature. On the contrary, the solubility decreased with increase in temperature. The Starch damage was rather affected by the milling process and not the drying process. Soaking period did not have noticeable significant effect on the functional properties compared with drying temperature.

\section{References}

[1] Adebowale, K.O., Olu-Owolabi,B.I., Olayinka,O.O. and Olayide,O.S. (2005). Effect of heat moist treatment and annealing on the physicochemical properties of red sorghum. African Journal of Biotechnology 4(9): 928-933.

[2] Adegunwa, M.O., Sanni, L. O. and Maziya-Dixon, B. (2011). Effects of fermentation length and varieties on the pasting properties of sour cassava starch. African Journal of Biotechnology, Vol. 10(42), pp. 8428-8433.

[3] Adeniji, A.O., and Porter, N.N. (1978). Properties of Ogi powders made from normal fortified and opaque-2 corn. J. Food Sci. 43: 1571.

[4] Aderiye, J. B. I., and Laleye, S. A. (2003).Relevance of fermented food products in southwest Nigeria.Plant Foods Human Nutr.58: $1-16$.

[5] Adeyemi, I. A. (1983).Dry-milling of sorghum for ogi manufacture. J. Cereal Sci. 1:221-227.

[6] Adeyemi, I.A., and Beckley, O., (1986). Effect of period of maize fermentation and souring on chemical properties and amylograph pasting viscosities of ogi. Cereal Sci. 4: 353-360.

[7] Ahenkora, K.S., Twumasi-Afriye, P.Y.K. Saalah and ObengAwtwi, K. (1999).Protein Nutritional quality and consumer acceptability of tropical Ghanaian quality protein maize.Food and Nutr. Bull. 20: 354-360.

[8] Ajayi, A.O. (2004). Emerging Roles for Extension in promoting Sustainable Rural Environment; lessons from Food Processing Cottage Industries and their Wastes in rural Oyo State, Nigeria. Retrieved from http://www.krepubli5hers.com/jQurnals/JHE/JHE16.

[9] Akalu, G., Johansson, G., and Nair, B.M. (19980. Effect of processing on the content of b-N-oxalyl-a,b-diaminopropionic acid (b-ODAP) in grasspea (Lathyrus sativus) seeds and our as determined by injection analysis. Food Chem. 62, 233-237.

[10] Akinrele, I.A. (1970). Fermentation studies on maize during the preparation of a traditional African Starch-cake food. Journal of the science of agriculture. 21 (12):619-625.

[11] Amarjeet, K., Bhupendar, S. and Sidhu, J.S.(1993) Studies on bread and durum wheat blends. Chem. Mikrobiol. Technol. Lebensm 15: 35-40.

[12] Aminigo, E. R and Akingbala, J.O. (2004). Nutritfive composition and sensory properties of ogi fortified with okra seed meal Journal of Applied Science and Environmental Management vol. 8 (2) 2328.

[13] Amoa, B., and Muller, H.G. (1976). Studies on kenkey with particular reference to calcium and phytic acid. Cereal chem. 53: 365-375.

[14] AOAC. (Association of Official Analytical Chemists) (2005). Official Methods of Analysis of the Association of Analytical Chemists International, 18th ed. Gathersburg, MD U.S.A Official methods, 2005.08.

[15] Banigo, E.O.I., and Muller, H.G. (1972a) Carboxylic acid patterns in ogi fermentation. Journal of Science Food and Agriculture 23 (1): 101-111. 
[16] Billiadris,C.G. (1982) Physical characteristics, enzymatic digestibility and structure of chemical modified smooth pea and waxy maize starches. Journal of Agricultural Food Chemistry 30: 925-930.

[17] Bolade, M.K., (2010). Evaluation of suitability of commercially available maize grains for 'tuwo' production in Nigeria. African Journal of Food Science Vol. 4(6), pp. 371-381.

[18] Coffman, C.W and Gracia, V.V. (1977). Functional properties and amino acids content of protein isolate from mung bean flour. J. Food Tech. 12: 473-484.

[19] Dengate, H.N. (1981). Swelling, pasting and gelling of wheat starch. Adv. Cereal Sci. Technol., 6, 49-82.

[20] Edema, M.O., Sanni, L.O., and Sanni, A.I. (2005). Evaluation of Maize-soybean flour blends for sour maize bread production in Nigeria. Afr. J.Biotechnol. 4: 911-917

[21] Faridi, H. (1990). Application of rheology in the cookie and cracker industry. In: Faridi H, Faubion JM (eds) Doughrheology and baked product texture, New York, USA, VanNostrand Reinhold. pp. 363-384.

[22] Fasasi, O.S., Adeyemi, I.A. and Fagbenro, O.A. (2007). Functional and pasting characteristics of fermented maize And nile tilapia (oreochromis niloticus) flour diet.Pakistan journal of nutrition 6 (4): 304-309.

[23] Fasasi, O.S., Adeyemi, I.A. and Fagbenro, O.A.(2005) Proximate composition and multi-enzyme in vitro protein digestibility of maize-tilapia flour blends. Journal of Food Technology 3(3): 342345.

[24] Hallauer, A.R., and Miranda, F.J.B. (1998).Quantitative genetics in maize breeding. Iowa State University Press: Ames, IA).

[25] Hoover, R. and Martin S.(1991) Isolation characterization of lima bean (Phaseolus lunatus) starch. Journal of Food Biochemistry 15: 1117-1136.

[26] Hoover, R. and Sosulski, F.W.(1986) Effect of cross-linking on functional properties of legume starches. Starch/Starke 38(5): 149155.

[27] .Kinsella, J.E.(1976) Functional properties of proteins in foods. Critical Reviews in Food Science and Nutrition 1(3): 219-280.

[28] Klaus, L., and Greg, H. (1976).Characteristic of Starches from Proso and foxtail millets. J. Agric. food chem. 24(5): 74-79.

[29] Leach, H.W., McCowen, L.D. and Scoch, T.J. (1959). Structure of starch granule 1.Swelling and solubilitypatterns of various starches. Cereal Chem., 36:534-544.

[30] Narayana, M., and Narasinga, S. (1984).Effect of partial proteolysis on the functional properties of winged bean (Phorsphocarpustetragonolobus) flour. J. Food Sci. 49: 944-947.

[31] Numfor, F.A., Walter, W.M Jr., Scwartz, S.J. (1996). physicochemical changes in Cassava starch and flour associated with fermentation effect in textural properties. Starch/Starke 1996, 47, 86-91.

[32] Odunfa, S.A. (1985): African fermented foods, In: Woods B.J.B (Ed). Microbiology of fermented foods, vol. 11, Amsterdam, Elsevier Applied Science Publishers. pp. 155-191.

[33] Odunfa, S.A., and Adeyele,S. (1985). Microbiological changes during the traditional production of ogibaba; a West African fermented sorghumgruel. J. Cereal Sci., 3: 173-180.

[34] Ohenhen, R.E., and Ikenemoh, M.J. (2007). Shelf Stability and Enzyme Activity Studies of Ogi: A corn Meal Fermented Product. J. Am. Sci. 3(1): 38-42.

[35] Okaka, J.C., and Potter, N.N. (1979). Physicochemical and functional properties of cowpea powders processed to reduce beany flavour. J. Food Sci. 44, 1235-1240.

[36] Okoruwa, A.E. (1997) Utilization and Processing of Maize. IITA Research Guide No. 35. IITA, Ibadan, Nigeria. pp. 5-16.
[37] Onitilo, M. O.; Sanni, L. O., Daniel, I., Maziya-Dixon, B. and Dixon, A. (2007) Physicochemical and Functional Properties of Native Starches from Cassava Varieties in Southwest Nigeria. Journal of Food, Agriculture and Environment Vol. 5(3\&4):108114.

[38] Onyekwere, O.O., Akinrele I.A and Koleoso O.A. (1989) Industrialization of ogi fermentation. In: Industrialization of indigenous fermented foods 33, 329-362.

[39] Oshodi, A.A. and Ekperigin, M.M.(1989) Functional properties of pigeon bean pea (Cajanus cajan) flour. Food Chemistry 34: 187199.

[40] Osungbaro, T.O. (1990a). Effect of differences in varieties and dry milling of maize on the textural characteristics of Ogi (fermented maize porridge) and agidi (fermented maize meal) J. Sci. Food Agric. 52: 1-12

[41] Osungbaro, T.O. (1990b). Effect of period on Amylose Content andTextural Characteristic of ogi (A fermented maize starch porridge) and agidi (fermented maize starch gel). J. Trop. Res. 14(1): 102-109.

[42] Otunola, E.T., Ogunsola, O., and Abioye, V.F. (2006): Effect of Tempeh on some properties of 'Agidi', a West African Fermented Maize Gel. Int. J. Food Agric. Res. 3(1): 119-128.

[43] Peroni, F.H.G., Rocha, T.S., and Franco, C.M.L.(2006). Some structural and physicochemical characteristics of tuber and root starches. International Journal of Food science and Technology, 12(6): 505-513.

[44] Ragaee, S., and Abdel-Aal, E.M. (2006).Pasting properties of starch and protein in selected cereals and quality of their food products. Food Chem. 95: 9-18.

[45] Raja, K. C. M., Ramakrishna, S. V. and Mathew, A. G. (1987), Effect of steam-hydrothermal treatment (SHTT) on the physicochemical properties of cassava (Manihot esculenta crantz) Journal of the science of food and agriculture. Journal Volume/Issue: 1987. v. 39 (1).

[46] Sacilik K. and Unal, G. (2005) Dehydration Characteristics of Kastamonu Garlic Slices Biosystems Engineering 92 (2), 207-215.

[47] Sasaki, T., and Matsuki, J., (1998).Effect of wheat starch structure on swelling power. Cereal Chemistry, 75: 525-529.

[48] Sathe, S.K., Deshpande, S.S., and Salunkhe, D.K. (1982a). Functional properties of winged bean (Psophocarpus tetragonolobus, L) proteins. J. Food Sci. 47: 503-506.

[49] Sathe, S.K., Deshpande, S.S., and Salunkhe, D.K. (1982b). Functional properties of winged bean (Psophocarpus tetragonolobus, L) proteins. J. Food Sci. 47: 503-509.

[50] Sefa-Dedeh, S.K.S., Asre, E.O. Dawson,S. and Afoakwa, E.O. (20020. Effect of fermentation and cowpea fortification on the quality characteristics of maiz based nixtamilized foods. http:/ ift.confex.com/ift/2002/ techprogram /meeting.

[51] Shi, Y.C., and Seib, P.A., (1994). Fine structure of maize starches from four wx-containing genotypes of the W64A inbred line in relation to gelatinization and retrogradation. Carbohydrate polymer, 26, 141-147.

[52] Spence, K.E., and Jane, J., (1999). Carbohydrate Polymers Volume 40, Issue 4, Pages 251-318.

[53] Tagodoe, A. and Nip, W.K.(1994) Functional properties of raw and precooked taro Colocasia esculenta flour. International Journal of Food Science and Technology 29: 457-482.

[54] Umoh, V. and Fields, M. (1981).Fermentation of corn for Nigeria agidi. J. Food Sci. 46:903-905.

[55] Vautsinas, L.P. and Nakai, S.(1983) A simple turbidimetric method of determining the fat binding capacity of proteins. Journal of Agricultural Food Chemistry 31: 58-61.

[56] Yaldiz O; Ertekin C; and Uzun H I (2001). Mathematical modeling of thin layer solar drying of Sultana grapes. Energy-An International Journal, 26, 457-465. 